\title{
Extracellular Calcium Regulates Postsynaptic Efficacy through Group 1 Metabotropic Glutamate Receptors
}

\author{
Neil R. Hardingham, ${ }^{1}$ Neil J. Bannister, ${ }^{1}$ Jenny C. A. Read, ${ }^{1}$ Kevin D. Fox, ${ }^{2}$ Giles E. Hardingham, ${ }^{3}$ and J. Julian B. Jack ${ }^{1}$ \\ ${ }^{1}$ The University Laboratory of Physiology, Oxford University, Oxford OX1 3PT, United Kingdom, ${ }^{2}$ The School of Biosciences, Cardiff University, Cardiff \\ CF10 3US, United Kingdom, and ${ }^{3}$ Centre for Neuroscience Research, Royal (Dick) School of Veterinary Studies, University of Edinburgh, Edinburgh EH9 \\ $1 \mathrm{QH}$, United Kingdom
}

\begin{abstract}
Bursts of synaptic transmission are known to induce transient depletion of $\mathrm{Ca}^{2+}$ within the synaptic cleft. Although Ca ${ }^{2+}$ depletion has been shown to lower presynaptic release probability, effects on the postsynaptic cell have not been reported. In this study, we show that physiologically relevant reductions in extracellular $\mathrm{Ca}^{2+}$ lead to a decrease in synaptic strength between synaptically coupled layer $2 / 3$ cortical pyramidal neurons. Using quantal analysis and mEPSP analysis, we demonstrate that a lowered extracellular $\mathrm{Ca}^{2+} \mathrm{produces} \mathrm{a}$ reduction in the postsynaptic quantal size in addition to its known effect on release probability. An elevated $\mathrm{Mg}^{2+}$ level can prevent this reduction in postsynaptic efficacy at subphysiological $\mathrm{Ca}^{2+}$ levels. We show that the calcium-dependent effect on postsynaptic quantal size is mediated by group 1 metabotropic glutamate receptors, acting via CaMKII ( $\mathrm{Ca}^{2+} /$ calmodulin-dependent protein kinase II) and PKC. Therefore, physiologically relevant changes in extracellular $\mathrm{Ca}^{2+}$ can regulate information transfer at cortical synapses via both presynaptic and postsynaptic mechanisms.
\end{abstract}

Key words: calcium [Ca]; metabotropic glutamate receptor; cortex; postsynaptic; CaMK-II; protein kinase C $\alpha$

\section{Introduction}

The role of $\mathrm{Ca}^{2+}$ ions is central to synaptic function, controlling both presynaptic release of neurotransmitter and induction of synaptic plasticity in the postsynaptic cell. There is mounting evidence that levels of extracellular calcium $\left(\left[\mathrm{Ca}^{2+}\right]_{\mathrm{ec}}\right)$ in the synaptic cleft can fall after periods of neuronal activity. For example, application of excitatory amino acids to the neocortex can cause 15 -fold reductions in $\left[\mathrm{Ca}^{2+}\right]_{\mathrm{ec}}$ to $<0.1 \mathrm{mM}$ (Pumain and Heinemann, 1985). Studies in the hippocampus have shown that, after a more physiological $10 \mathrm{~Hz}$ synaptic stimulation for several seconds, free $\left[\mathrm{Ca}^{2+}\right]_{\mathrm{ec}}$ can fall from 2 to $1.5 \mathrm{~mm}$ (Nicholson et al., 1977). A reduction in the size of the presynaptic $\mathrm{Ca}^{2+}$ current has been reported after a prolonged ( $100 \mathrm{~ms}$ pulse) depolarization of the presynaptic or postsynaptic membrane, which was attributed to $\mathrm{Ca}^{2+}$ depletion in the cleft (Borst and Sakmann, 1999). Modeling studies indicate that the degree of $\mathrm{Ca}^{2+}$ depletion is highly dependent on firing frequency (Vassilev et al., 1997). However, other factors such as receptor channel density, glia, and synapse size are also important. (Egelman and Montague, 1999; Rusakov, 2001). Detailed compartmental models of the synaptic cleft suggest that shifts in $\left[\mathrm{Ca}^{2+}\right]_{\mathrm{ec}}$ can occur after a single presynaptic action potential (Rusakov et al., 1999). The flow of $\mathrm{Ca}^{2+}$ through NMDA receptors also contributes to a reduction of available

Received Dec. 2, 2005; revised May 4, 2006; accepted May 4, 2006.

This work was supported by The Wellcome Trust, The Medical Research Council (United Kingdom), and the Royal Society.

Correspondence should be addressed to Dr. Neil R. Hardingham, Biosi 3, The School of Biosciences, Cardiff University, Museum Avenue, Cardiff CF10 3US, UK. E-mail: sbinrh@cardiff.ac.uk.

DOI:10.1523/JNEUROSCI.5128-05.2006

Copyright $\odot 2006$ Society for Neuroscience $\quad$ 0270-6474/06/266337-09\$15.00/0
$\mathrm{Ca}^{2+}$ ions in the synaptic cleft. (Egelman and Montague, 1998, 1999; Rusakov and Fine, 2003). Furthermore, dendritic spiking may also significantly deplete local $\mathrm{Ca}^{2+}$ (Wiest et al., 2000). It therefore appears that after synaptic stimulation both presynaptic and postsynaptic elements are competing for the available $\mathrm{Ca}^{2+}$ in the synaptic cleft.

Given this evidence of activity-dependent $\mathrm{Ca}^{2+}$ depletion at central synapses, we decided to examine how changes in $\left[\mathrm{Ca}^{2+}\right]_{\mathrm{ec}}$ may affect the strength of synapses between cortical pyramidal neurons in layer $2 / 3$ of the rat visual cortex. To examine presynaptic and postsynaptic determinants, the trialto-trial distribution of EPSP amplitudes were subjected to a quantal analysis (Del Castillo and Katz, 1954). Quantal analysis has been used with reluctance at central synapses because of problems of nonuniform release probability (Walmsley et al., 1988) and high quantal variance (Stricker and Redman, 2003). However, using brain slices from more mature animals greatly reduces quantal variance (Wall and Usowicz, 1998). Studies in the hippocampus have suggested that quantal variance is low enough to attempt an analysis between 3 and 4 weeks of age (Stricker et al., 1996). In addition, it has also been shown recently that release probabilities at different boutons of a given layer $2 / 3$ pyramidal connection in the rat neocortex are comparable (Koester and Johnston, 2005), suggesting that a simple binomial model of transmitter release may be a valid description at these synapses.

A quantal analysis of layer $2 / 3$ excitatory cortical connections reveals that, in addition to the reduction in presynaptic efficacy, a drop in $\left[\mathrm{Ca}^{2+}\right]_{\mathrm{ec}}$ causes a significant reduction in quantal size (a measure of postsynaptic efficacy), which is 
mediated via postsynaptic group 1 metabotropic glutamate receptors (mGluR1s).

\section{Materials and Methods}

Slice preparation and intracellular recording. All recordings were made from brain slices taken from 19- to 27-d-old Sprague Dawley rats. Animals were killed by cervical dislocation and parasagittal slices of visual cortex (400 $\mu \mathrm{m}$ thick) were prepared by conventional methods (Hardingham and Larkman, 1998). Slices were maintained at $23^{\circ} \mathrm{C}$ in artificial CSF (ACSF) containing the following (in $\mathrm{mm}$ ): $119 \mathrm{NaCl}, 3.5 \mathrm{KCl}, 1$ $\mathrm{NaH}_{2} \mathrm{PO}_{4}, 2.5 \mathrm{CaCl}_{2}, 1 \mathrm{MgSO}_{4}, 26 \mathrm{NaHCO}_{3}$, and 10 glucose, bubbled with $95 \% \mathrm{O}_{2}$ and $5 \% \mathrm{CO}_{2}$.

Whole-cell voltage recordings were made from the somata of closely adjacent pairs of pyramidal neurons within layer $2 / 3$ (predominantly layer 2) of the visual cortex, selected by near-infrared differential interference contrast video microscopy (Dodt and Zieglgansberger, 1990) using a Zeiss (Oberkochen, Germany) Axioskop upright microscope equipped with a $40 \times$ water-immersion objective. Recording pipettes contained the following (in $\mathrm{mm}$ ): 110 potassium gluconate, $10 \mathrm{KCl}, 2$ $\mathrm{MgCl}_{2}, 2 \mathrm{Na}_{2} \mathrm{ATP}, 10 \mathrm{EGTA}, 2 \mathrm{CaCl}_{2}$ and 10 HEPES, adjusted to $\mathrm{pH}$ 7.3, and $270 \mathrm{mOsm}$. Before seal formation, neurons were selected as pyramidal by the presence of a prominent apical dendrite. Subsequently, the neuron could be identified as a pyramid by its asymmetric spikes, typical of pyramidal neurons in this layer (McCormick et al., 1985; Mason et al., 1991).

Single action potentials were elicited (by current injection) in one neuron and on-line spike-triggered averaging was used to detect any resultant EPSP elicited in the other neuron. If no EPSP could be detected, the pair of cells was tested for a connection in the other direction. Once a synaptic connection had been identified, single action potentials were induced in the presynaptic cell at 0.1 or $0.2 \mathrm{~Hz}$ by injection of short $(5-10$ $\mathrm{ms}$ ) pulses of depolarizing current. Postsynaptic responses were amplified, low-pass filtered at $2 \mathrm{kHz}$, digitized at $5 \mathrm{kHz}$ using a CED (Cambridge Electronic Design, Cambridge, UK) 1401 analog-to-digital board and recorded on a PC for analysis off-line. Postsynaptic neurons were held at membrane potentials more negative than $-70 \mathrm{mV}$ to ensure that EPSPs were dominated by AMPA currents but holding current was rarely necessary. Slices were continually perfused with ACSF during recording.

After control periods of recording at $2.5 \mathrm{~mm}\left[\mathrm{Ca}^{2+}\right]_{\mathrm{ec}}$, the $\left[\mathrm{Ca}^{2+}\right]_{\mathrm{ec}}$ and in some cases $\left[\mathrm{Mg}^{2+}\right]_{\mathrm{ec}}$ were changed by perfusing the recording bath with an ACSF solution containing a different concentration of cation(s) and/or other drugs. At least 20 min of recordings were made after each solution change to ensure equilibration. To verify that changes in divalent cation concentrations were not mediating their effects via changes in the membrane properties of cells, we monitored the input resistance $\left(R_{\mathrm{in}}\right)$ and membrane time constant of the cell $\left(\tau_{\mathrm{m}}\right)$. No significant change in either $R_{\mathrm{in}}$ or $\tau_{\mathrm{m}}$ was observed after the changes we made to the ionic composition of the ACSF.

AP5 $(50 \mu \mathrm{M})$, picrotoxin $(100 \mu \mathrm{M})$, TTX (1 $\mu \mathrm{M})$, AP3 (1 mM), 7-(hydroxyimino)cyclopropachromen-1a-carboxylateethyl ester (CPCCOEt; $50 \mu \mathrm{M}$ ) and (RS)-3,5-dihydroxyphenylglycine (DHPG; $100 \mu \mathrm{M})$ ) were bath applied. Pertussis toxin $(1 \mu \mathrm{g} / \mathrm{ml}), 2$-[1-(3-dimethylaminopropyl)-1H-indol-3-yl]-3-(1H-indol-3-yl)maleimide (GF109203X; $100 \mu \mathrm{M}), \quad 1-[N, \mathrm{Q}-$ bis(5-isoquinolinesulfonyl)- $N$-methyl-L-tyrosyl $]-4-$ phenylpiperazine (KN62) (50 $\mu \mathrm{M}), N$-(2-aminoethyl)-5-isoquinolinesulfonamide hydrochloride (H9) $(10 \mu \mathrm{M})$, microcystin $(10 \mu \mathrm{M})$, and cyclosporin $(10 \mu \mathrm{M})$ were all applied intracellularly via the patch electrode. All drugs were purchased from Tocris (Bristol, UK).

Measurement of EPSP amplitude. For each EPSP recorded, the peak amplitude from each spike-triggered sweep was measured off-line using a computer routine that compared the average voltage during a $0.4-2 \mathrm{~ms}$ period of baseline potential with the average voltage during a period of the same duration at the EPSP peak. For each EPSP, the measurement windows were determined from the averaged EPSP waveform. Measurements of noise were obtained using the same time windows used to measure the EPSP, but implemented in an area of baseline remote from the EPSP. At least three separate noise measurements were taken for each EPSP from nonoverlapping parts of the baseline to calculate the mean noise SD. This noise SD was subtracted from the EPSP SD using the equation $(\text { EPSP SD })^{2}=(\text { SD of combined EPSP }+ \text { noise })^{2}-($ noise SD $)^{2}$. To verify that the postsynaptic changes in EPSP amplitude we observed in these experiments were changes in AMPA currents, we sought to verify that the EPSPs we were recording at $-70 \mathrm{mV}$ were exclusively AMPA mediated. In $50 \mu \mathrm{M}$ APV, EPSPs were on average $1.06 \pm 0.04$ times their control value $(n=5)$. Therefore NMDA receptors do not appear to contribute significantly to EPSPs recorded at $-70 \mathrm{mV}$.

Selection of EPSP data. Only EPSP recordings remaining stable for at least 100 consecutive trials of the control period of recording were included in the final data set. Stable periods of data were defined as those in which the mean and SD, taken over successive epochs of 50 trials, remained close to their values for the first epoch. The SD was required to remain within $30 \%$ of its initial value, whereas the mean amplitude was required to remain within three times the $\mathrm{SE}$ of the first epoch (approximately $\pm 0.5 \mathrm{SD}$ ). A study in the hippocampus has suggested that there could be significant drifts in quantal size over time (Larkman et al., 1997), which were sometimes associated with inverse changes in release probability, with no net effect on the mean amplitude (A.U. Larkman, unpublished observations). This possibility is minimized by imposing stability criteria on the SD as well as on the mean amplitude because, for a binomial process, changes in release probability only minimally affect the SD, whereas changes in quantal size have a much greater effect on the SD.

Extracting quantal parameters. Histograms of amplitude frequency distributions of EPSPs from stable periods of data often $(\cong 50 \%$ of recordings) contained regularly spaced peaks, indicative of a quantal release of neurotransmitter at the synapses. It has been shown that neocortical synapses relating to individual connections appear to operate with similar release probabilities, which are target derived (Koester and Johnston, 2005) and so can be approximated with a simple binomial model. Therefore, the working hypothesis was that the EPSP amplitudes were drawn from a simple binomial distribution characterized by the number of release sites $(N)$, release probability $\left(P_{r}\right)$, and quantal size $(Q)$ (Larkman et al., 1997). Experimental noise was represented as a Gaussian with SD $\sigma_{n}$. We incorporated an offset $S$ to allow for the fact that the mean amplitude of failures may differ slightly from zero, because of extracellular field effects (Stricker et al., 1996). Finally, we included a parameter $\sigma_{Q}$ representing quantal variance.

Models were fitted to experimental data using the method of maximum likelihood (Press et al., 1993). The noise $\sigma_{n}$ was obtained by fitting a single Gaussian function to a noise distribution measured from the postsynaptic neuron. For a given number of release sites, $N$, the continuously variable parameters $\left(P_{r}, Q, \sigma_{Q}, S\right)$ were then fitted to the data so as to maximize the likelihood $\left(L_{N}\right)$. The optimal $N$ was defined to be that with the highest $L_{N}$. Starting from $N=1, N$ was increased until it was either four larger than the $N$ value with the highest $L_{N}$ so far encountered, or 20, whichever occurred first.

Locating a global maximum in a multidimensional parameter space is a nontrivial matter. It was performed with the fminsearch algorithm from MATLAB's Optimization Toolbox. To guard against being misled by a local maximum, every fit was repeated with 10 different randomly chosen starting positions in the parameter space. During development, the performance of this algorithm was validated against a simulated annealing algorithm (Press et al., 1993) implemented in $\mathrm{C}++$, repeated with three different cooling regimes (J. C. Read, unpublished observation).

For each EPSP recording in the final data set, we fitted at least one period of stable data (recorded in $2.5 \mathrm{~mm}\left[\mathrm{Ca}^{2+}\right]_{\mathrm{ec}}$ ) with a simple binomial model. This provided us with a model for the connection at $2.5 \mathrm{~mm}$ $\left[\mathrm{Ca}^{2+}\right]_{\mathrm{ec}}$, including the number of release sites $(N)$, the release probability $\left(P_{r}\right)$, and the quantal size $(Q)$. We made the assumption that $N$ remained constant during the remainder of the recording, and so could be constrained in subsequent fits to the remaining data sets from that connection.

Adequacy of fitted model. To test whether the proposed fit was acceptable as a model of the experimental data, seven goodness-of-fit statistics were considered: the Kolmogorov-Smirnov $D$ statistic (Press et al., 1993), the sum of the squared differences between the model and data cumulative distributions, and the $\chi^{2}$ statistic for five different bin sizes. The power of the $\chi^{2}$ statistic depends strongly on the bin size used. With 
too few bins, the test is too coarse to catch local deviations of the data from the model predictions. Conversely, if too many bins are used, the number of data points falling in any one bin is small and subject to large sampling fluctuations, so the statistic again tolerates poor fits. The optimal number of bins depends on the data set. By using a range of different bin numbers $(20,30,50,75$, and 100) for each data set, we ensured that each data set would be exposed to a rigorous test. The distributions of these statistics under the null hypothesis, that the experimental data had actually been drawn from the fitted model, were obtained by Monte Carlo simulation (implemented in MATLAB on a personal computer). Five thousand sets of simulated data, each the same size as the experimental data set, were generated from the fitted model, and the seven goodness-of-fit statistics were calculated for each simulated data set. For each statistic, we calculated what proportion $(f)$ of simulated data sets yielded higher values of the statistic (indicating worse fits) than the experimental data. A value of $f>5 \%$ means that the null hypothesis cannot be rejected at the $5 \%$ level on the basis of the statistic. Finally, we applied an additional test, using the proportion of events that failed to evoke a simulated EPSP, $p_{\text {fail }}$. The Monte Carlo distribution of failure rates could then be compared with the $p_{\text {fail }}$ observed experimentally. The failure rate test is a two-tailed test, so the null hypothesis is accepted at the $5 \%$ level provided that the experimental $p_{\text {fail }}$ lies in between the 2.5 and $97.5 \%$ quantiles of the Monte Carlo distribution. The quantal models describing each period of experimental data were not accepted if any of our tests provided evidence to reject the null hypothesis at the $5 \%$ level. For approximately half of our recordings, we were unable to obtain a satisfactory binomial model, similar to the proportion reported by (Koester and Johnston, 2005). This was either as a result of the fitting algorithm being unable to compute an optimal solution, or because the model failed on one or more of the rigorous statistical tests.

Miniature EPSPs. Miniature EPSPs (mEPSPs) were recorded from a different population of layer $2 / 3$ pyramidal neurons at $2.5 \mathrm{~mm}\left[\mathrm{Ca}^{2+}\right]_{\mathrm{ec}} / 1$ $\mathrm{mm}\left[\mathrm{Mg}^{2+}\right]_{\mathrm{ec}}$ and $1 \mathrm{~mm}\left[\mathrm{Ca}^{2+}\right]_{\mathrm{ec}} / 1 \mathrm{~mm}\left[\mathrm{Mg}^{2+}\right]_{\mathrm{ec}}$ in the presence of 50 $\mu \mathrm{M}$ APV, $1 \mu \mathrm{M}$ TTX, and $100 \mu \mathrm{M}$ picrotoxin. The mEPSP files were analyzed blind and EPSPs were identified by eye on the basis of their rapid rise and slow decay times. Their amplitudes were determined using a computer optimizing routine that fitted the sum of two exponential functions (rise and decay) to each mEPSP (Hardingham and Larkman, 1998). A total of $250 \mathrm{mEPSPs}$ were measured for each of four neurons and pooled to give an mEPSP amplitude distribution of 1000 events, initially at $2.5 \mathrm{mM} \mathrm{Ca}^{2+}{ }_{\text {ec }}$, then at $1.0 \mathrm{mM} \mathrm{Ca}^{2+}{ }_{\text {ec }}$, and then again at 2.5 $\mathrm{mm}$. This experiment was performed at both 23 and $34^{\circ} \mathrm{C}$.

Unless otherwise stated, values quoted are mean \pm SEM. Statistical tests for differences between populations were made using paired $t$ tests.

\section{Results}

\section{EPSP size behaves as a function of $\left[\mathrm{Ca}^{2+}\right]_{\mathrm{ec}}$}

To investigate the effect of $\left[\mathrm{Ca}^{2+}\right]_{\mathrm{ec}}$ on synaptic efficacy, we recorded EPSPs from synaptically connected layer $2 / 3$ cells in supraphysiological $(2.5 \mathrm{~mm})$ and subphysiological $(1 \mathrm{mM})\left[\mathrm{Ca}^{2+}\right]_{\mathrm{ec}}$, maintaining $\left[\mathrm{Mg}^{2+}\right]_{\mathrm{ec}}$ at $1 \mathrm{~mm}$ (Fig. 1). In all cases, the mean EPSP amplitude dropped after $\left[\mathrm{Ca}^{2+}\right]_{\mathrm{ec}}$ was lowered. On average, the mean EPSP amplitude recorded in $1.0 \mathrm{~mm}\left[\mathrm{Ca}^{2+}\right]_{\mathrm{ec}}$ was a quarter $(26 \pm 3 \%)$ of that recorded in $2.5 \mathrm{~mm}\left[\mathrm{Ca}^{2+}\right]_{\mathrm{ec}}$ (Fig. $\left.1 c\right)$ $(n=10)$. On returning to $2.5 \mathrm{~mm}\left[\mathrm{Ca}^{2+}\right]_{\mathrm{ec}}$, the mean EPSP amplitude returned to close to the initial value observed before the drop in $\left[\mathrm{Ca}^{2+}\right]_{\mathrm{ec}}$ (Fig. 1).

To investigate in detail the locus of the change in synaptic efficacy, we used quantal analysis methods. Optimal binomial model fits to EPSP amplitude histograms recorded in $2.5 \mathrm{~mm}$ $\left[\mathrm{Ca}^{2+}\right]_{\mathrm{ec}}$ returned values for quantal size $(Q)$ that were consistent with the spacings between peaks from Gaussian filtered histograms (Figs. 2a,b). We were unable to obtain a simple binomial model fit to approximately half of our recorded synaptic connections, consistent with previous studies (Koester and Johnston, 2005). The mean quantal amplitude $(Q)$ obtained from these fits at $2.5 \mathrm{~mm}\left[\mathrm{Ca}^{2+}\right]_{\mathrm{ec}}$ was $271 \pm 21 \mu \mathrm{V}(n=10$ connections $)$. To

\section{a}$$
\begin{aligned}
& 3 \\
& 3 \\
& \frac{0}{3} \\
& \frac{1}{0} \\
& \text { है } \\
& 0 \\
& 0 \\
& \frac{0}{4}
\end{aligned}
$$

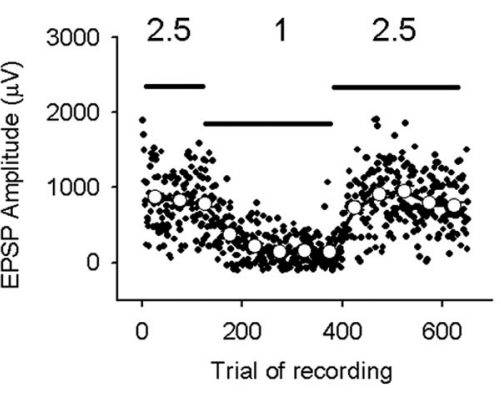

b

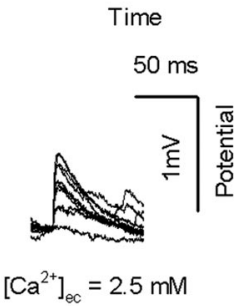

C
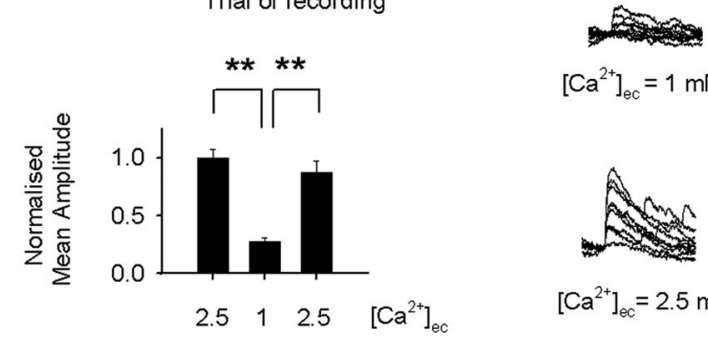

$\left[\mathrm{Ca}^{2+}\right]_{\mathrm{eC}}=1 \mathrm{mM}$

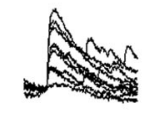

$\left[\mathrm{Ca}^{2+}\right]_{\mathrm{eC}}=2.5 \mathrm{mM}$

Figure 1. Extracellular $\left[\mathrm{Ca}^{2+}\right]$ regulates EPSP amplitude of paired recordings between layer 2/3 neurons. $\boldsymbol{a}$, Trial-to-trial measurements of EPSP amplitudes (filled circles) and mean EPSP amplitude per 50 trial epoch (open circles) from a single experiment. Recordings were first made in ACSF containing $2.5 \mathrm{~mm}\left[\mathrm{Ca}^{2+}\right]_{\mathrm{ec}}\left(150\right.$ trials), and then $1 \mathrm{~mm}\left[\mathrm{Ca}^{2+}\right]_{\mathrm{ec}}(250$ trials $)$ and back to $2.5 \mathrm{~mm}\left[\mathrm{Ca}^{2+}\right]_{\mathrm{ec}}\left(250\right.$ trials). $\left[\mathrm{Mg}^{2+}\right]_{\mathrm{ec}}$ was maintained at $1 \mathrm{~mm}$ throughout. $\boldsymbol{b}$, Individual traces taken from periods of stable recording in each $\left[\mathrm{Ca}^{2+}\right]_{\mathrm{ec}}$. For each example, 10 consecutive EPSPs are overlaid. c, Summary data showing the effect of $\left[\mathrm{Ca}^{2+}\right]_{\mathrm{ec}}$ on mean EPSP amplitude (normalized, $n=10$ ). ${ }^{* *} p<0.01$. Error bars indicate SE.

verify that the derived models yielded realistic values for $Q$, we compared estimates for $Q$ (derived from modeling) with amplitudes of spontaneous miniature EPSPs (mEPSPs) recorded from similar cells in TTX, APV, and picrotoxin. The mean amplitude of mEPSPs (from four cells) was $298 \pm 4 \mu \mathrm{V}(n=500)$, which was not significantly different to the derived values of quantal size ( $p>0.05$ ), suggesting that the values obtained for $Q$ were reliable measurements of single vesicular release.

Our initial assumption was that the reduction in mean EPSP amplitude observed when $\left[\mathrm{Ca}^{2+}\right]_{\mathrm{ec}}$ was lowered from 2.5 to $1 \mathrm{mM}$ was purely attributable to a reduction in release probability (a presynaptic effect). The presynaptic $\mathrm{Ca}^{2+}$ current $\left(I_{\mathrm{Ca}}\right)$ has been previously shown to be proportional to $\left[\mathrm{Ca}^{2+}\right]_{\mathrm{ec}}$ (i.e., $I_{\mathrm{Ca}} \propto$ $\left[\mathrm{Ca}^{2+}\right]_{\mathrm{ec}}$ ) (Mintz et al., 1995). An entirely presynaptic change would involve no postsynaptic change (in $Q$ ) on varying $\left[\mathrm{Ca}^{2+}\right]_{\mathrm{ec}}$. To test this hypothesis, stable periods of data recorded during periods of low $\left[\mathrm{Ca}^{2+}\right]_{\mathrm{ec}}(1 \mathrm{~mm})$ were fitted with a binomial model constraining $Q$ to the value derived from the same connection in $2.5 \mathrm{mM} \mathrm{Ca}^{2+}$. In all cases $(n=10)$, models constraining $Q$ to $Q_{2.5}$ were inadequate in describing the $1 \mathrm{~mm} \mathrm{Ca}^{2+}$ data (Fig. 2c). When the data were refitted, this time allowing $Q$ to optimize, adequate fits were returned with smaller $Q$ values than obtained at $2.5 \mathrm{mM} \mathrm{Ca}^{2+}$ (Fig. 2d). On average, the mean quantal size at $1.0 \mathrm{~mm}\left[\mathrm{Ca}^{2+}\right]_{\mathrm{ec}}$ was $64 \pm 4 \%$ of that measured from the same connection recorded in $2.5 \mathrm{~mm}\left[\mathrm{Ca}^{2+}\right]_{\mathrm{ec}}$ (Fig. 2e).

To confirm that the reduction in $Q$ with $\left[\mathrm{Ca}^{2+}\right]_{\mathrm{ec}}$ was reversible, for each connection, we recorded a second period of data in $2.5 \mathrm{~mm}\left[\mathrm{Ca}^{2+}\right]_{\mathrm{ec}}$. In all cases, models fitted to this later period of data in $2.5 \mathrm{~mm} \mathrm{Ca}^{2+}$ constraining $Q$ to that recorded in $1 \mathrm{~mm}$ $\mathrm{Ca}^{2+}$ were again found to be inadequate $(n=10)$ (supplemental Fig. 1e, available at www.jneurosci.org as supplemental material). However, models constraining $Q$ to that recorded initially in 2.5 $\mathrm{mM}\left[\mathrm{Ca}^{2+}\right]_{\mathrm{ec}}$ were considered adequate (supplemental Fig. 1, available at www.jneurosci.org as supplemental material). Con- 
a

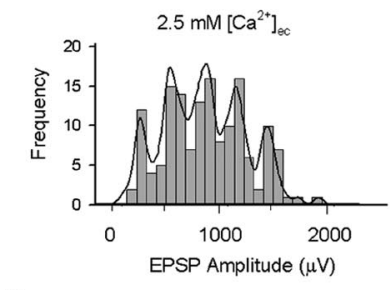

C

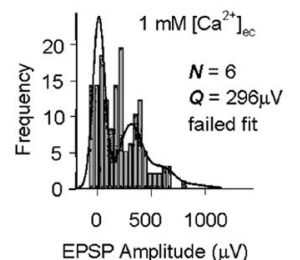

e

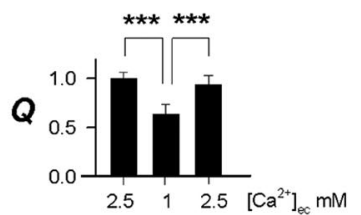

g

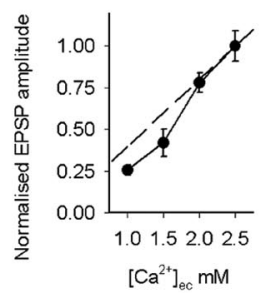

$\mathrm{b}$

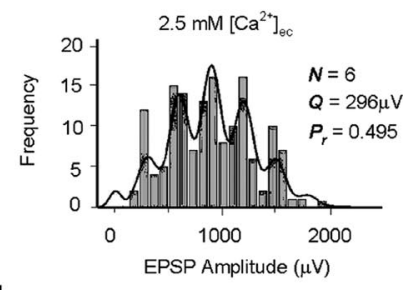

d

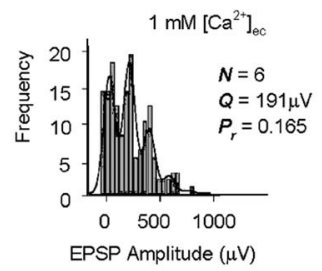

f

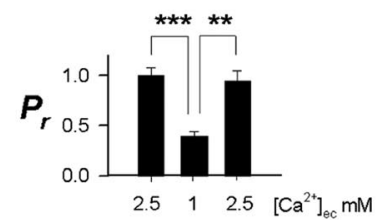

$\mathrm{h}$

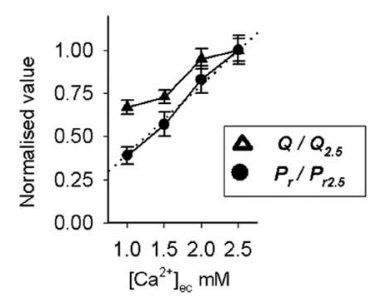

Figure 2. $\left[\mathrm{Ca}^{2+}\right]_{\mathrm{ec}}$ regulates quantal size as well as release probability. $\boldsymbol{a}$, Amplitude frequency histogram for the first stable period of data shown in Figure 1 (vertical bars, recorded in $2.5 \mathrm{~mm} \mathrm{Ca}^{2+}$ ) and a Gaussian filtered version of it (solid line). $\boldsymbol{b}$, The highest likelihood quantal model (solid line) shows similar peak spacing to the filtered data and is adequate in describing the data. Values for the number of release sites $(N)$, quantal size $(Q)$ and release probability $\left(P_{r}\right)$ predicted by the model are given. $c$, The highest likelihood quantal model constraining $Q$ to $Q_{2.5}$ $(296 \mu \mathrm{V})$ is inadequate in describing data recorded from the same connection at $1 \mathrm{~mm}\left[\mathrm{Ca}^{2+}\right]_{\mathrm{ec}}$. $\boldsymbol{d}$, The highest likelihood quantal model allowing free fitting of $Q$ successfully fits the $1 \mathrm{~mm}$ $\left[\mathrm{Ca}^{2+}\right]_{\mathrm{ec}}$ data with a much lower $Q$ of $191 \mu$ V.e, Summary data showing the effect of $\left[\mathrm{Ca}^{2+}\right]_{\mathrm{ec}}$ on quantal size ( $n=10$ connections, values normalized to initial recording in $\left.2.5 \mathrm{~mm} \mathrm{Ca}^{2+}\right)$. $f$, Summary data showing the effect of $\left[\mathrm{Ca}^{2+}\right]_{\mathrm{ec}}$ on release probability $(n=10$ connections, values normalized to initial recording in $\left.2.5 \mathrm{~mm} \mathrm{Ca}^{2+}\right)$. $g$, Relationship between mean EPSP amplitude and $\left[\mathrm{Ca}^{2+}\right]_{\mathrm{ec}}$. Amplitudes are normalized to data recorded in $2.5 \mathrm{~mm}\left[\mathrm{Ca}^{2+}\right]_{\mathrm{ec}} \cdot \boldsymbol{h}$, Relationship between $Q /\left[\mathrm{Ca}^{2+}\right]_{\mathrm{ec}}$ and $P_{r} /\left[\mathrm{Ca}^{2+}\right]_{\mathrm{ec}}$ Values are normalized to data recorded in $\left[\mathrm{Ca}^{2+}\right]_{\mathrm{ec}}$ Error bars indicate SE. ${ }^{* *} p<0.01 ;{ }^{* * *} p<0.001$

sistent with this result, subsequent fits to the second epoch of data recorded in $2.5 \mathrm{~mm}\left[\mathrm{Ca}^{2+}\right]_{\mathrm{ec}}$, this time allowing $Q$ to optimize, returned values for $Q$ that were similar to the initial values of $Q$ recorded in $2.5 \mathrm{~mm}\left[\mathrm{Ca}^{2+}\right]_{\mathrm{ec}}(93.9 \pm 5.1 \%$ ) (Fig. 2e, supplemental Fig. 1, available at www.jneurosci.org as supplemental material). These results provide evidence of considerable (and reversible) postsynaptic modification in response to lowering $\left[\mathrm{Ca}^{2+}\right]_{\mathrm{ec}}$ from 2.5 to $1 \mathrm{~mm}$.

In addition to obtaining values for quantal size $(Q)$ from EPSP recordings, we also derived values for $P_{r}$. The mean release probability in $2.5 \mathrm{~mm}\left[\mathrm{Ca}^{2+}\right]_{\mathrm{ec}}$ was $0.50 \pm 0.05(n=10)$. Mean $P_{r}$ dropped to $0.17 \pm 0.01$ in $1 \mathrm{~mm}\left[\mathrm{Ca}^{2+}\right]_{\mathrm{ec}}$ (a reduction of $61 \pm$ $4 \% ; n=10)$ (Fig. 2f). This reduction is very similar to the drop in $P_{r}$ that would be seen if there was a linear relationship between $\left[\mathrm{Ca}^{2+}\right]_{\mathrm{ec}}$ and synaptic release. The failure rate for EPSPs at 2.5

$\mathrm{mm}\left[\mathrm{Ca}^{2+}\right]_{\mathrm{ec}}$ was $0.17 \pm 0.04$, which is consistent with that reported for paired recordings from layer $\mathrm{V}$ pyramidal connections in rat cortex of similar age (Markram et al., 1997). The mean number of release sites $(N)$, derived from quantal analysis methods, was $3.9 \pm 0.8$, which is again similar to the number of contacts that have been found between paired cortical neurons, assuming one functional synapse per anatomical connection (Feldmeyer et al., 1999).

We next sought to investigate in more detail the relationship between $\left[\mathrm{Ca}^{2+}\right]_{\mathrm{ec}}$ and synaptic parameters $P_{r}$ and $Q$. EPSPs were recorded in a series of $\left[\mathrm{Ca}^{2+}\right]_{\mathrm{ec}}$ from 1 to $2.5 \mathrm{~mm}$ (Figs. $\left.2 g, h\right)(n=$ 8 connections). Data recorded at each $\left[\mathrm{Ca}^{2+}\right]_{\mathrm{ec}}$ were fitted with a binomial model allowing the estimate of $Q$ to be optimized. The relationship of mean EPSP amplitude with $\left[\mathrm{Ca}^{2+}\right]_{\mathrm{ec}}$ showed a slope greater than unity, especially between 1.5 and $2 \mathrm{~mm}$ $\left[\mathrm{Ca}^{2+}\right]_{\text {ec }}$ (Fig. $2 g$ ), but when changes in mean amplitudes were separated into changes in $Q$ and $P_{r}$, neither slope was significantly greater than unity (Fig. $2 h$ ). This finding suggests an absence of cooperativity between $\left[\mathrm{Ca}^{2+}\right]_{\mathrm{ec}}$ and vesicular release at cortical synapses, because $P_{r}$ appears only to increase linearly with $\left[\mathrm{Ca}^{2+}\right]_{\mathrm{ec}}$. Quantal amplitudes were as follows: $0.67 \pm 0.04 Q_{2.5}$ at $1 \mathrm{~mm}\left[\mathrm{Ca}^{2+}\right]_{\mathrm{ec}}, 0.73 \pm 0.04 Q_{2.5}$ at $1.5 \mathrm{~mm}\left[\mathrm{Ca}^{2+}\right]_{\mathrm{ec}}$ and $0.95 \pm$ $0.05 Q_{2.5}$ at $2.0 \mathrm{~mm}\left[\mathrm{Ca}^{2+}\right]_{\mathrm{ec}}$ (Fig. $2 h$ ).

\section{mEPSP amplitudes show a similar dependence on extracellular calcium to $Q$}

We next sought to confirm our findings regarding the change in $Q$ with $\left[\mathrm{Ca}^{2+}\right]_{\mathrm{ec}}$ using an alternative technique. Miniature EPSPs (mEPSPs) are triggered by single spontaneous vesicular releases at excitatory synapses and provide an alternative means to measure quantal size.

The mean amplitude of mEPSP, recorded in TTX, APV, and picrotoxin, dropped by $32 \pm 2 \%$ after a reduction in $\left[\mathrm{Ca}^{2+}\right]_{\mathrm{ec}}$ from 2.5 to $1 \mathrm{~mm}$ (Fig. 3a). This is comparable with the reduction in quantal amplitude observed in connections between synaptically coupled pairs of neurons $(36 \pm 4 \%)$. Experiments performed at more physiological temperatures $\left(34^{\circ} \mathrm{C}\right)$ again showed very similar changes (Fig. $3 b)(28 \pm 2 \%)$, and the effect was also reversible. mEPSPs had average $10-90 \%$ rise times of $3.5 \pm 0.04$ $\mathrm{ms}(n=2000)$, which were again highly comparable with the rise times of EPSPs from paired recordings [mean 10-90\% rise time, $3.3 \pm 0.2 \mathrm{~ms}(n=10)]$. We were therefore satisfied that the two experimental approaches were sampling from the same population of synapses. mEPSPs are widely regarded to be uniquantal, and changes in amplitude reflect a postsynaptic modification. However, an alternative explanation of our data is that a proportion of mEPSPs recorded at $2.5 \mathrm{mM} \mathrm{Ca}^{2+}$ are multiquantal, and the apparent change in quantal size with calcium represents a presynaptic effect. To investigate this possibility, we plotted amplitude frequency distribution plots for mEPSPs at 2.5 and $1 \mathrm{mM}$ $\mathrm{Ca}^{2+}$ and measured their median and skew values (Fig. 3c,d). At $1 \mathrm{mM} \mathrm{Ca}^{2+}$, median values showed a comparable drop to mean amplitude from that obtained at $2.5 \mathrm{mM} \mathrm{Ca}^{2+}\left[68 \pm 4 \%, 23^{\circ} \mathrm{C}\right.$ (Fig. $3 d$ ) and $71 \pm 3 \%, 34^{\circ} \mathrm{C}$ (data not shown)] whereas skew values were unchanged $\left[106 \pm 9 \%, 23^{\circ} \mathrm{C}\right.$ (Fig. $3 d$ ) and $105 \pm$ $14 \%, 34^{\circ} \mathrm{C}$ (data not shown)]. This is consistent with a postsynaptic effect because any presynaptic effect would result in a change in the skew of the distribution and a greater change in median than mean amplitude.

$\left[\mathrm{Mg}^{2+}\right]_{\mathrm{ec}}$ can replicate the postsynaptic effect of $\left[\mathrm{Ca}^{2+}\right]_{\mathrm{ec}}$ Previous studies investigating the role of extracellular $\mathrm{Ca}^{2+}$ on synaptic function compensated for the reduction in divalent cat- 
a

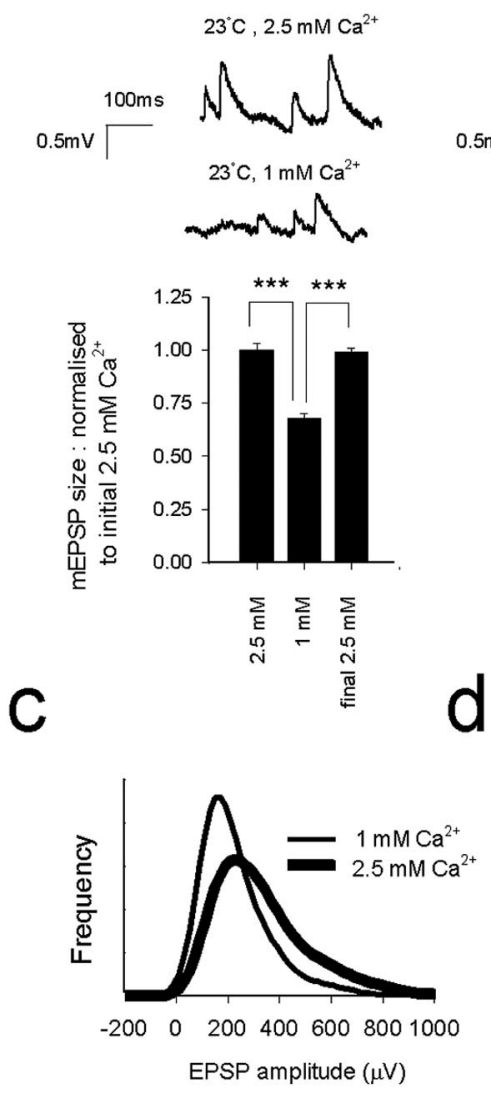

b

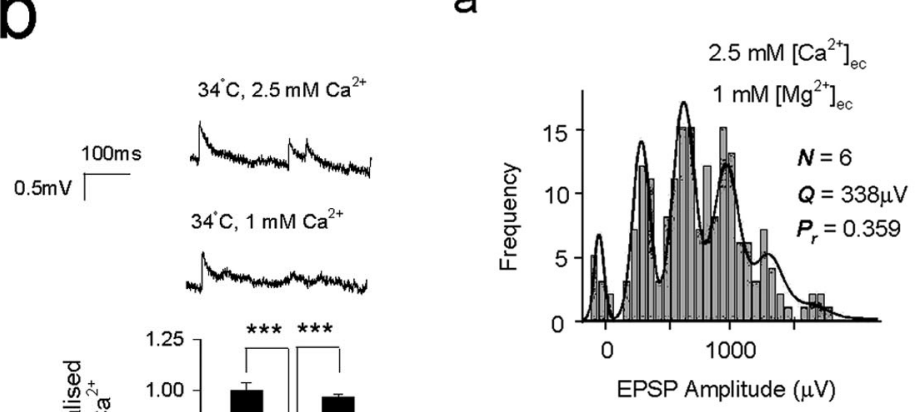

b

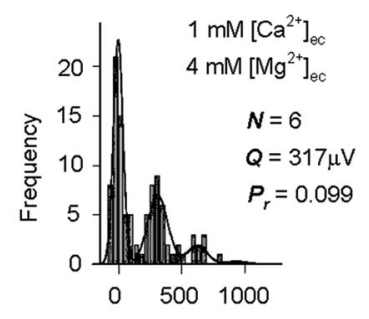

EPSP Amplitude $(\mu \mathrm{V})$ ${ }^{* * *} p<0.001$.

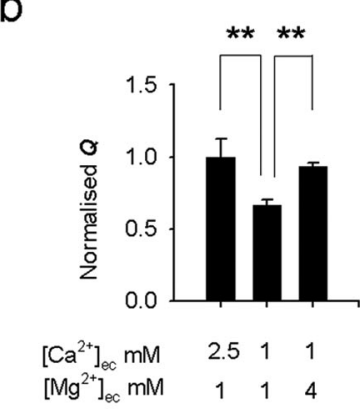

C

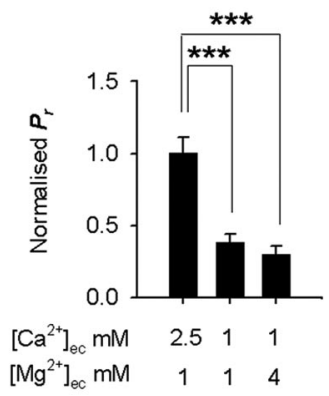

Figure 4. The reduction in $Q$ on lowering $\left[\mathrm{Ca}^{2+}\right]_{\mathrm{ec}}$ is prevented by elevated $\left[\mathrm{Mg}^{2+}\right]_{\mathrm{ec}} \cdot \boldsymbol{a}$, EPSP amplitude frequency distributions (filtered) from recordings made in $2.5 \mathrm{~mm}\left[\mathrm{Ca}^{2+}\right]_{\mathrm{ec}} / 1$ $\mathrm{mm}\left[\mathrm{Mg}^{2+}\right]_{\mathrm{ec}}$ (top) and $1 \mathrm{~mm}\left[\mathrm{Ca}^{2+}\right]_{\mathrm{ec}} / 4 \mathrm{~mm}\left[\mathrm{Mg}^{2+}\right]_{\text {ec }}$ (bottom) taken from a single experiment. The model fit for each distribution is indicated by a solid line, with values for $N, P_{r}$ and $Q$ shown. Summary data shows the effect of divalent ion concentration $\left(\left[\mathrm{Ca}^{2+}\right]_{\mathrm{ec}}\right.$ and $\left.\left[\mathrm{Mg}^{2+}\right]_{\mathrm{ec}}\right)$ on quantal size (b) and release probability (c) ( $n=8$ connections), with values normalized to initial values obtained in $2.5 \mathrm{~mm}\left[\mathrm{Ca}^{2+}\right]_{\mathrm{ec}} / 1 \mathrm{~mm}\left[\mathrm{Mg}^{2+}\right]_{\mathrm{ec}}$. Error bars indicate $S E .{ }^{* *} p<0.01$;

compensating surface charge by elevating $\left[\mathrm{Mg}^{2+}\right]_{\mathrm{ec}}$ largely blocks the reduction in $Q$ seen in subphysiological $\left[\mathrm{Ca}^{2+}\right]_{\mathrm{ec}}$. This may explain why the postsynaptic effects of changes in $\left[\mathrm{Ca}^{2+}\right]_{\mathrm{ec}}$ have not been previously detected.

Figure 3. The effect of $\left[\mathrm{Ca}^{2+}\right]_{\mathrm{ec}}$ on mEPSPs. The effect of reducing $\left[\mathrm{Ca}^{2+}\right]_{\mathrm{ec}}$ from 2.5 to $\mathrm{mm}$ on miniature EPSPs recorded in TTX, picrotoxin, and APV is shown in $\boldsymbol{a}$ at $23^{\circ} \mathrm{C}$ and in $\boldsymbol{b}$ at $34^{\circ} \mathrm{C}$. Example traces are shown at both temperatures. $c$, The effect of $\left[\mathrm{Ca}^{2+}\right]_{\mathrm{ec}}$ on the mEPSP amplitude distribution from a single cell is illustrated. Individual amplitudes are filtered with a Gaussian (data recorded at $23^{\circ} \mathrm{C}$ ). $\boldsymbol{d}$, Effect of lowered $\left[\mathrm{Ca}^{2+}\right]_{\mathrm{ec}}$ on median amplitude of the distributions is comparable with the effect of $\left[\mathrm{Ca}^{2+}\right]_{\mathrm{ec}}$ on the mean amplitude, although there is no effect on the skew of the distributions (data recorded at $23^{\circ} \mathrm{C}$ ). Effects on median amplitude and skew were comparable at $34^{\circ} \mathrm{C}$ (data not shown). Statistics given are comparisons between mEPSP populations recorded at 2.5 and $1.0 \mathrm{~mm} \mathrm{Ca}^{2+}$. Error bars indicate SE. ${ }^{* * *} p<$ 0.001

ions by an elevated $\left[\mathrm{Mg}^{2+}\right]_{\mathrm{ec}}$ (Silver et al., 2003). This substitution does not presumably occur in vivo where, if anything, $\left[\mathrm{Mg}^{2+}\right]_{\mathrm{ec}}$ would also fall slightly after synaptic stimulation. We therefore investigated whether the postsynaptic effects brought about by lowering $\left[\mathrm{Ca}^{2+}\right]_{\mathrm{ec}}$ could be prevented by compensatory increases in $\left[\mathrm{Mg}^{2+}\right]_{\mathrm{ec}}$. Conventionally, $\mathrm{Ca}^{2+}$ is replaced with twice the amount of $\mathrm{Mg}^{2+}$ because of the weaker $\mathrm{Mg}^{2+}$ surface charge effects (Hille et al., 1975). To investigate this idea, EPSPs were recorded in a series of three different extracellular divalent ion concentration combinations $\left(2.5 \mathrm{mM} \mathrm{Ca}^{2+}: 1 \mathrm{mM} \mathrm{Mg}^{2+} ; 1\right.$ $\mathrm{mM} \mathrm{Ca}^{2+}: 1 \mathrm{mM} \mathrm{Mg}^{2+}$; and $1 \mathrm{mM} \mathrm{Ca}^{2+}: 4 \mathrm{mM} \mathrm{Mg}^{2+} ; n=8$ cells) (Fig. 4). In all cases, models constraining $Q$ to that measured in $2.5 \mathrm{Ca}^{2+}: 1 \mathrm{Mg}^{2+}$ were adequate in describing the data in 1 $\mathrm{Ca}^{2+}: 4 \mathrm{Mg}^{2+}$ (Fig. 4a), but inadequate in describing the data in 1 $\mathrm{Ca}^{2+}: 1 \mathrm{Mg}^{2+}$. Models fitted to data recorded in $1 \mathrm{Ca}^{2+}: 4 \mathrm{Mg}^{2+}$, allowing optimal fitting of $Q$, returned values for $Q$ that were close to $Q_{2.5 \mathrm{Ca}}(0.93 \pm 0.07)$ (Fig. $\left.4 b\right)$. Reductions in $P_{r}$ from 2.5 $\mathrm{Ca}^{2+}: 1 \mathrm{Mg}^{2+}$ to $1 \mathrm{Ca}^{2+}: 4 \mathrm{Mg}^{2+}$ were slightly larger than in 1 $\mathrm{Ca}^{2+}: 4 \mathrm{Mg}^{2+}$, which might be expected from the antagonistic action of the $\mathrm{Mg}^{2+}$ ion on synaptic release (Fig. 4c). Therefore,

\section{mGluR1 mediates the effect of $\left[\mathrm{Ca}^{2+}\right]_{\mathrm{ec}}$ on $Q$}

We next investigated the signaling mechanism by which $\left[\mathrm{Ca}^{2+}\right]_{\mathrm{ec}}$ regulates $Q$. One possibility is the postsynaptic $m G l u R$, which has been shown to be sensitive to both glutamate and $\mathrm{Ca}^{2+}{ }_{\mathrm{ec}}$, and the $\mathrm{IC}_{50}$ for $\mathrm{Ca}^{2+}$ is within the physiological range of the synaptic cleft (Kubo et al., 1998; Francesconi and Duvoisin, 2004). Potentiating effects of mGluRs on excitatory cortical transmission have been demonstrated previously (Wang and Daw, 1996; Bandrowski et al., 2001; Jin et al., 2001; Iserhot et al., 2004); the most likely mGluRs to be involved in this process are the group 1 mGluRs, which are exclusively located postsynaptically (Lujan et al., 1997). Furthermore, mGluR1 has been shown to be activated by $\mathrm{Mg}^{2+}$ as well as $\mathrm{Ca}^{2+}$ (Francesconi and Duvoisin, 2004), making them worthy of investigation given our observation in Figure 4.

In recordings made in $2.5 \mathrm{~mm}\left[\mathrm{Ca}^{2+}\right]_{\mathrm{ec}}$, bath application of either AP3 (a group 1 mGluR antagonist; $n=7$ ) or CPCCOEt (a specific antagonist of mGluR1; $n=3$ ) produced similar reductions in $Q$ to those observed on reducing $\left[\mathrm{Ca}^{2+}\right]_{\mathrm{ec}}$ from 2.5 to 1 $\mathrm{mm}$ (compare Figs. 2e, 5a). Bath application of the selective group 1 mGluR agonist (DHPG; $n=10$ ), however, had no significant effect on $Q$ (Fig. $5 a$ ) when compared with control conditions. Conversely, at low $(1 \mathrm{mM})\left[\mathrm{Ca}^{2+}\right]_{\mathrm{ec}}$, application of AP3 $(n=5)$ produced no change in $Q$, whereas DHPG $(n=5)$ produced a significant $Q$ increase (Fig. 5b). This increase in $Q$ was similar to that observed on increasing $\left[\mathrm{Ca}^{2+}\right]_{\mathrm{ec}}$ from 1 to $2.5 \mathrm{~mm}$ (Fig. $2 e$ ). 
Inclusion of DHPG in the bath solution prevented the drop in $Q$ normally observed when $\left[\mathrm{Ca}^{2+}\right]_{\mathrm{ec}}$ was reduced from 2.5 to $1 \mathrm{~mm}(n=6)$ (Fig. 5 , compare $c$, top and bottom, $d)$, but had no effect on the drop in $P_{r}$ observed (Fig. $\left.5 e\right)(n=6)$. Therefore, it appears that the control of $Q$ by $\left[\mathrm{Ca}^{2+}\right]_{\mathrm{ec}}$ is mediated by mGluRs that have low activity at $1 \mathrm{~mm}\left[\mathrm{Ca}^{2+}\right]_{\mathrm{ec}}$ and higher activity at $2.5 \mathrm{~mm}\left[\mathrm{Ca}^{2+}\right]_{\mathrm{ec}}$. Application of either of the group 1 antagonists AP3 or CPCCOEt, or the group 1 agonist DHPG had no significant effect on $P_{r}$, either at 2.5 or $1 \mathrm{~mm}\left[\mathrm{Ca}^{2+}\right]_{\mathrm{ec}}$ (data not shown).

\section{Canonical group $1 \mathrm{mGluR}$ signaling regulates $Q$ via $\left[\mathrm{Ca}^{2+}\right]_{\mathrm{ec}}$}

Activation of group $1 \mathrm{mGluRs}$ is known to increase levels of active PKC and $\mathrm{Ca}^{2+}$ / calmodulin-dependent protein kinase II (CaMKII) via liberation of DAG and $\mathrm{IP}_{3}$ respectively, through the activation of phospholipase C via Gq (Gudermann et al., 1996). PKC and CaMKII are known to be capable of modulation of AMPA channels (Carroll et al., 1998). In a final series of experiments, we sought to explore the signaling cascades that were mediating the $\left[\mathrm{Ca}^{2+}\right]_{\mathrm{ec}} / \mathrm{mGluR} 1$ effect downstream of the mGluRs.

In these experiments, measures of $Q$ were made from EPSPs initially recorded in $1 \mathrm{~mm}\left[\mathrm{Ca}^{2+}\right]_{\mathrm{ec}}$ and then at $2.5 \mathrm{mM}\left[\mathrm{Ca}^{2+}\right]_{\mathrm{ec}}$. Under control conditions, $Q$ increased by $39 \%$ when $\left[\mathrm{Ca}^{2+}\right]_{\mathrm{ec}}$ was thus increased (mean $Q_{2.5[\mathrm{Ca}]}: Q_{1[\mathrm{Ca}]}$ ratio was $1.39 \pm 0.05$ ) (Fig. $6 a$ ). The inclusion of pertussis toxin (a G-protein inhibitor) in the patch pipette ( $n=5$ cells), blocked this increase in $Q$ (Fig. $6 a$ ). Equally, inclusion of the CaMKII inhibitor (KN62; $n=4$ cells) or PKC inhibitor (GF109203X; $n=4$ ) in the patch pipette blocked the increase in quantal size (Fig. 6a). In contrast, the PKA inhibitor (H9; $n=4$ cells) had no significant effect on the $\mathrm{Q} / \mathrm{Ca}^{2+}$ change (Fig. 6a).

As well as establishing the postsynaptic kinases involved in phosphorylating the AMPA channels and increasing $Q$ on elevating $\left[\mathrm{Ca}^{2+}\right]_{\mathrm{ec}}$, we were also interested in establishing the counterbalancing phosphatases involved in the reduction of $Q$ on lowering $\left[\mathrm{Ca}^{2+}\right]_{\mathrm{ec}}$.

Microcystin was used to inhibit protein phosphatases 1 and 2A (Thomas et al. 1997). This blocked the reduction in $Q$ on lowering $\left[\mathrm{Ca}^{2+}\right]_{\mathrm{ec}}$ (Fig. $\left.6 b\right)(n=4)$. Cyclosporin was used to block protein phosphatase 2B (Thomas et al., 1997). This drug had no effect on the reduction in $Q$ observed in going from supraphysiological to subphysiological $\left[\mathrm{Ca}^{2+}\right]_{\mathrm{ec}}$ (Fig. $\left.6 b\right)(n=4)$.

\section{Discussion}

Our key finding is that variations of $\left[\mathrm{Ca}^{2+}\right]_{\mathrm{ec}}$ within the physiological range can affect quantal size as well as the probability of release at central synapses. Effects of $\mathrm{Ca}^{2+}$ on synaptic release at both central and peripheral synapses are well documented (Augustine, 2001) but effects on $Q$ have been largely overlooked up to now. Although the effect of $\left[\mathrm{Ca}^{2+}\right]_{\mathrm{ec}}$ is not as great on $Q$ as on $P_{r}$, it does mean that attempts to measure the cooperativity of $\mathrm{Ca}^{2+}$ in central synaptic release need to be interpreted with caution,
C

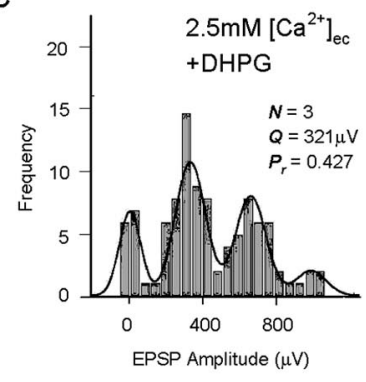

d

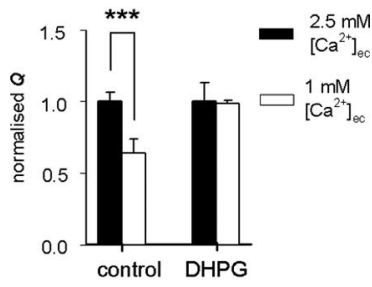

e
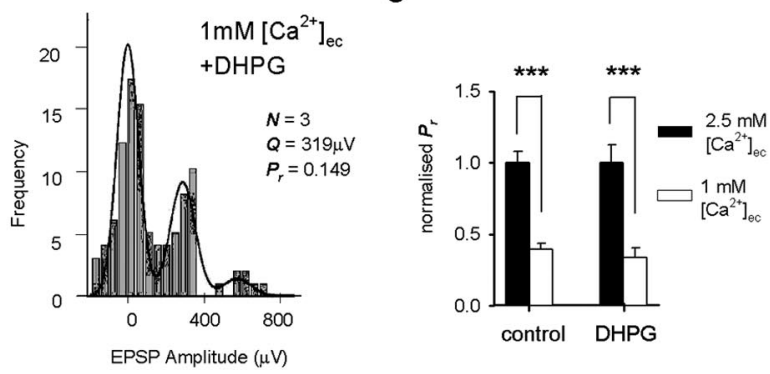

a

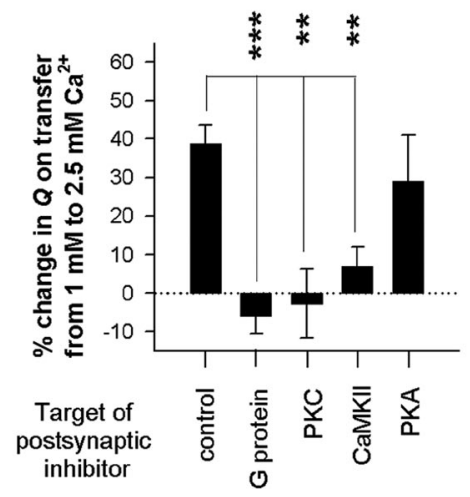

b

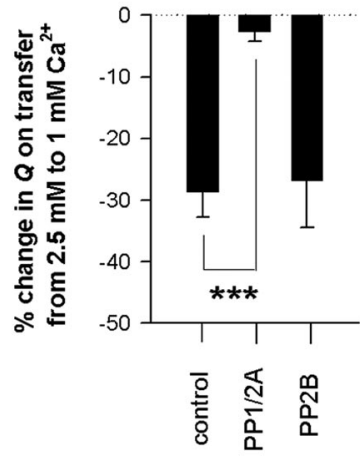

Figure 6. The effect on Q is mediated by canonical type $1 \mathrm{mGluR}$ signaling. $\boldsymbol{a}$, Summary data showing the effect of the G-protein inhibitor (pertussis toxin, $1 \mu \mathrm{g} / \mathrm{ml} ; n=5$ ), the PKC inhibitor (GF109203X, $100 \mu \mathrm{m} ; n=5)$, the CaMKII inhibitor (KN62, $50 \mu \mathrm{m} ; n=4)$ ), and the PKA inhibitor ( $\mathrm{H} 9,10 \mu \mathrm{m} ; n=4)$ on preventing the increase in quantal size $(Q)$ observed under control conditions when $\left[\mathrm{Ca}^{2+}\right]_{\mathrm{ec}}$ is raised from 1 to $2.5 \mathrm{~mm}$. Results are expressed as the percentage increase in $Q$ measured in $2.5 \mathrm{~mm} \mathrm{Ca}^{2+}{ }_{\text {ec }}$ compared with that recorded in $1 \mathrm{~mm} \mathrm{Ca}^{2+}{ }_{\text {ec }} \boldsymbol{b}$, Summary data showing the effect of the protein phosphatase blockers microcystin $(10 \mu \mathrm{m} ; n=$ 4) and cyclosporin (10 $\mu \mathrm{m} ; n=4)$ on preventing the reduction in quantal size (Q) observed under control conditions when $\left[\mathrm{Ca}^{2+}\right]_{\mathrm{ec}}$ is reduced from 2.5 to $1 \mathrm{~mm}$. Results are expressed as the percentage reduction in $Q$ measured in $1 \mathrm{~mm} \mathrm{Ca}^{2+}{ }_{\text {ec }}$ compared with that measured in 2.5 $\mathrm{mm} \mathrm{Ca}^{2+}{ }_{\text {ec }}$ Error bars indicate SE. ${ }^{* * *} p<0.001 ;{ }^{* *} p<0.01$.

particularly where release is measured postsynaptically (Goda and Stevens, 1994; Mintz et al., 1995; Qian and Noebels, 2001). Nevertheless, the wide range in cooperativity values obtained at central synapses, from 1 (Augustine, 1990) to 3.5 and 4 (Goda and Stevens, 1994; Qian and Noebels, 2001) are unlikely to be 
explained by the postsynaptic effect on $Q$ that we have reported. A more likely explanation of these observations is that synaptic release machinery can operate with different levels of cooperativity at the same synapse (the Calyx of Held), depending on the intracellular $\left[\mathrm{Ca}^{2+}\right]\left(\left[\mathrm{Ca}^{2+}\right]_{\mathrm{ic}}\right)$ after stimulation (Lou et al., 2005).

In our data, the dependence of synaptic release $\left(P_{r}\right)$ on $\left[\mathrm{Ca}^{2+}\right]_{\mathrm{ec}}$ is close to linear $(n=1.03)$, whereas the effect on $Q(n=$ $0.44)$ is sublinear. The overall cooperativity at these synapses is close to 1.5 , as a result of both of these effects.

\section{The mechanism for the change in quantal size}

The identification of cell surface detectors of $\mathrm{Ca}^{2+}$ ec has put forward the question of whether $\mathrm{Ca}^{2+}$ also functions as an extracellular signaling molecule in the brain (Bouschet and Henley, 2005). The prototypical $\mathrm{Ca}^{2+}{ }_{\text {ec }}$ sensing receptor $(\mathrm{CaR})$ was initially cloned in the parathyroid gland (Brown et al., 1993) and is expressed in varying amounts in many tissues, including the CNS, specifically concentrated at nerve terminals (Ruat et al., 1995). Group 1 mGluRs are structurally similar to CaR (Hermans and Challiss, 2001), both operate via G-proteins (Brown and MacLeod, 2001), and have been reported to also have significant sensitivity to $\left[\mathrm{Ca}^{2+}\right]_{\mathrm{ec}}$ (Kubo et al., 1998; Francesconi and Duvoisin, 2004). Heterodimerization of CaR with Group 1 mGluRs has also been shown to take place in hippocampal and cerebellar neurons (Gama et al., 2001). An important question to ask will be whether $\mathrm{CaR}$ heterodimerizes to mGluRs in the intact brain or whether mGluR expresses its sensitivity to $\mathrm{Ca}^{2+}$ without binding to $\mathrm{CaR}$.

Other divalent cations (e.g., $\mathrm{Mg}^{2+}, \mathrm{Zn}^{2+}$ ) have also been shown to activate mGluRs in combination with glutamate (Francesconi and Duvoisin, 2004), which is consistent with the results from this study where $\mathrm{Mg}^{2+}$ can prevent the drop in $Q$ at low $\left[\mathrm{Ca}^{2+}\right]_{\mathrm{ec}}$ (Fig. 4) and may explain why the $Q$ reduction has not been observed previously, as $\mathrm{Ca}^{2+}$ is often replaced with $\mathrm{Mg}^{2+}$ at reduced $\left[\mathrm{Ca}^{2+}\right]_{\mathrm{ec}}$ (Silver et al., 1996). More recent work suggests that changes in $\left[\mathrm{Ca}^{2+}\right]_{\mathrm{ec}}$ can alter the range of concentrations of agonist to which the group 1 metabotropic glutamate receptor (mGluR1) responds (Tabata et al., 2002), shifting the dynamic range to include lower concentrations by up to 100 -fold. Because DHPG and glutamate have similar agonist affinities (Conn and Pin, 1997), this implies that at resting concentrations of $\mathrm{Ca}^{2+}$ (1.5-2 mM) (Cohen and Fields, 2004) and glutamate (0.5-2 $\mu \mathrm{M})$ (Meldrum, 2000; Cavelier et al., 2005), a significant percentage of the mGluR1 receptors may be "constitutively" active, but become inactivated as $\left[\mathrm{Ca}^{2+}\right]_{\mathrm{ec}}$ is lowered.

In the CNS, a variety of effects produced by mGluR1 have been described. The group 1 mGluRs (mGluR1 and mGluR5) activate CaMKII and PKC via phospholipase $\mathrm{C} \alpha$ (Berridge and Irvine, 1984; Hermans and Challiss, 2001). Activated CaMKII and PKC have both been shown to phosphorylate AMPA receptors on the serine 831 (s831) site (Tan et al., 1994; Barria et al., 1997; Mammen et al., 1997), which increases the single channel current. The average increase in mean AMPA channel conductance from either CaMKII or PKC is of the order of $30-40 \%$ (Carroll et al., 1998; Derkach et al., 1999), and basal phosphorylation of the s831 site has been suggested (Mammen et al., 1997). The drop in $Q$ we observed on reducing $\left[\mathrm{Ca}^{2+}\right]_{\mathrm{ec}}$ to $1 \mathrm{~mm}$ was $36 \%$, with a comparable drop in the mean amplitude of mEPSPs $(32 \%)$. This approximate alignment in the magnitude of the change, coupled with the effects of CaMKII and PKC antagonists, strongly suggests that the drop in $Q$ at lowered $\left[\mathrm{Ca}^{2+}\right]_{\mathrm{ec}}$ is ex- plained by a loss of AMPA receptor phosphorylation at the s831 site.

Although our results suggest that the effect of $\left[\mathrm{Ca}^{2+}\right]_{\mathrm{ec}}$ on $Q$ is mediated by postsynaptic mGluRs, another possibility is that $\mathrm{Ca}^{2+}$ is having a direct effect on the AMPA current. However, the $\mathrm{Ca}^{2+}$ permeability of AMPA receptors in pyramidal neurons of rat neocortex of similar age to that used in our study has been shown to be low [ratio of $\mathrm{Ca}^{2+}$ to monovalent permeability of $\sim 0.05$ (Jonas et al., 1994)], suggesting that it is unlikely that the reduction in quantal size we observed in this study at lowered $\left[\mathrm{Ca}^{2+}\right]_{\mathrm{ec}}$ is caused by a reduction in $\mathrm{Ca}^{2+}$ ions flowing through AMPA channels.

Another possibility is that $\mathrm{Ca}^{2+}$ is having a direct modulatory effect at the AMPA receptor. Recently it has been demonstrated that divalent cations can act like competitive antagonists at the AMPA receptor (Dorofeeva et al., 2005). The effect we report in this study is a reduction in AMPA current with lowering of $\left[\mathrm{Ca}^{2+}\right]_{\mathrm{ec}}$. This is the opposite of what would be expected if $\mathrm{Ca}^{2+}$ was acting as an antagonist, and therefore cannot explain our observations.

A further possibility is that the reduction in $Q$ is caused by a diminished release of transmitter from the vesicle, akin to the mechanisms discussed by Chen et al. (2004). There is clear evidence at some central synapses (cerebellum, hippocampus, Calyx of Held) that activation of mGluR1 can cause a presynaptic inhibition, arising from the postsynaptic release of endocannabinoids (Morishita et al., 1998; Maejima et al., 2001; Kushmerick et al., 2004). Decreases in $\left[\mathrm{Ca}^{2+}\right]_{\mathrm{ec}}$ have been shown to activate voltage-dependent outward currents in synaptosomes and may, in this way, modulate the excitability of the presynaptic terminal (Smith et al., 2004). Our results (including mEPSP analysis) are not readily compatible with a presynaptic mechanism, as it might be expected that the degree of glutamate release from an individual vesicle would also be linked to a change in $P_{r}$ (for a discussion of mechanisms, see Chen et al., 2004); in our experiments, neither agonist nor antagonist produced a consistent change in $P_{r}$ at either 1 or $2.5 \mathrm{~mm}\left[\mathrm{Ca}^{2+}\right]_{\mathrm{ec}}$, so we regard a presynaptic explanation of the change in $Q$ as highly unlikely.

\section{Does the mechanism for change in $Q$ operate physiologically?}

The rationale for performing our experiments was that there was evidence that $\left[\mathrm{Ca}^{2+}\right]_{\mathrm{ec}}$ can fall during normal physiological function (Massimini and Amzica, 2001; Cohen and Fields, 2004). We therefore explored the effect of lowered $\left[\mathrm{Ca}^{2+}\right]_{\mathrm{ec}}$ without reproducing the exact physiological circumstances in which this effect is reported to occur. The lowered $\left[\mathrm{Ca}^{2+}\right]_{\mathrm{ec}}$ effect normally occurs after a period of excitatory synaptic activity, particularly if there is sufficient excitatory depolarization to cause inward current through the NMDA receptors (Rusakov and Fine, 2003). We have interpreted our data as implying that a fall in $\left[\mathrm{Ca}^{2+}\right]_{\mathrm{ec}}$ may lower the sensitivity of the mGluR1 to ambient agonists (i.e., glutamate) and, hence, reduce activation of the mGluR1 receptor.

However, the decrease in $\left[\mathrm{Ca}^{2+}\right]_{\mathrm{ec}}$ is evoked by release of glutamate and, hence, occurs in circumstances when [glut $]_{\mathrm{ec}}$ should be raised. Thus, initially these two extracellular effects may cancel each other out and the possibility of decreased activation of the mGluR1 would only occur if the decreased $\left[\mathrm{Ca}^{2+}\right]_{\mathrm{ec}}$ outlasted the increased [glut $]_{\mathrm{ec}}$. Both modeling and experimental studies indicate that is indeed likely to occur, providing the $\left[\mathrm{Ca}^{2+}\right]_{\mathrm{ec}}$ depletion is partly caused by functional activation of the NMDA receptors, because elevated [glut $]_{\mathrm{ec}}$ is relatively rapidly cleared by the glutamate transporter, whereas the $\mathrm{Ca}^{2+}$ depletion 
can continue for longer than 100 ms. (Rusakov, 2001; Rusakov and Fine, 2003). The kinetics for activation and deactivation of mGluR1 are not known, but there may be an adequate period of lowered $\left[\mathrm{Ca}^{2+}\right]_{\mathrm{ec}}$ in near normal ambient glutamate to allow for deactivation of the mechanism. Further exploration of the mechanism would be desirable, not only in terms of the kinetics, but also with respect to the effect of different levels of the ambient agonists; GABA may also extend sensitivity of the receptor to glutamate (Tabata et al., 2004). This may be fundamental to the type and duration of plasticity induced in an experimental preparation (Braunewell et al., 2003; van Dam et al., 2004) because there is some evidence that in vitro and in vivo preparations may have different ambient levels of transmitters such as glutamate (Cavelier et al., 2005). This may in turn be one contributing factor in explaining the diversity of results that have been obtained for long-term potentiation and long-term depression experiments (van Dam et al., 2004).

\section{References}

Augustine GJ (1990) Regulation of transmitter release at the squid giant synapse by presynaptic delayed rectifier potassium current. J Physiol (Lond) 431:343-364.

Augustine GJ (2001) How does calcium trigger neurotransmitter release? Curr Opin Neurobiol 11:320-326.

Bandrowski AE, Aramakis VB, Moore SL, Ashe JH (2001) Metabotropic glutamate receptors modify ionotropic glutamate responses in neocortical pyramidal cells and interneurons. Exp Brain Res 136:25-40.

Barria A, Derkach V, Soderling T (1997) Identification of the $\mathrm{Ca}^{2+}$ / calmodulin-dependent protein kinase II regulatory phosphorylation site in the alpha-amino-3-hydroxyl-5-methyl-4-isoxazole-propionate-type glutamate receptor. J Biol Chem 272:32727-32730.

Berridge MJ, Irvine RF (1984) Inositol trisphosphate, a novel second messenger in cellular signal transduction. Nature 312:315-321.

Borst JG, Sakmann B (1999) Depletion of calcium in the synaptic cleft of a calyx-type synapse in the rat brainstem. J Physiol (Lond) 521:123-133.

Bouschet T, Henley JM (2005) Calcium as an extracellular signalling molecule: perspectives on the calcium sensing receptor in the brain. C R Biol 328:691-700.

Braunewell KH, Brackmann M, Manahan-Vaughan D (2003) Group I mGlu receptors regulate the expression of the neuronal calcium sensor protein VILIP-1 in vitro and in vivo: implications for mGlu receptordependent hippocampal plasticity? Neuropharmacology 44:707-715.

Brown EM, MacLeod RJ (2001) Extracellular calcium sensing and extracellular calcium signaling. Physiol Rev 81:239-297.

Brown EM, Gamba G, Riccardi D, Lombardi M, Butters R, Kifor O, Sun A, Hediger MA, Lytton J, Hebert SC (1993) Cloning and characterization of an extracellular $\mathrm{Ca}^{2+}$-sensing receptor from bovine parathyroid. Nature 366:575-580.

Carroll RC, Nicoll RA, Malenka RC (1998) Effects of PKA and PKC on miniature excitatory postsynaptic currents in CAl pyramidal cells. J Neurophysiol 80:2797-2800.

Cavelier P, Hamann M, Rossi D, Mobbs P, Attwell D (2005) Tonic excitation and inhibition of neurons: ambient transmitter sources and computational consequences. Prog Biophys Mol Biol 87:3-16.

Chen G, Harata NC, Tsien RW (2004) Paired-pulse depression of unitary quantal amplitude at single hippocampal synapses. Proc Natl Acad Sci USA 101:1063-1068.

Cohen JE, Fields RD (2004) Extracellular calcium depletion in synaptic transmission. Neuroscientist 10:12-17.

Conn PJ, Pin JP (1997) Pharmacology and functions of metabotropic glutamate receptors. Annu Rev Pharmacol Toxicol 37:205-237.

Del Castillo J, Katz B (1954) Quantal components of the end-plate potential. J Physiol (Lond) 124:560-573.

Derkach V, Barria A, Soderling TR (1999) $\mathrm{Ca}^{2+} /$ calmodulin-kinase II enhances channel conductance of alpha-amino-3-hydroxy-5-methyl-4isoxazolepropionate type glutamate receptors. Proc Natl Acad Sci USA 96:3269-3274.

Dodt HU, Zieglgansberger W (1990) Visualizing unstained neurons in living brain slices by infrared DIC-videomicroscopy. Brain Res 537:333-336.
Dorofeeva NA, Tikhonov DB, Barygin OI, Tikhonova TB, Salnikov YI, Magazanik LG (2005) Action of extracellular divalent cations on native alphaamino-3-hydroxy-5-methylisoxazole-4-propionate (AMPA) receptors. J Neurochem 95:1704-1712.

Egelman DM, Montague PR (1998) Computational properties of peridendritic calcium fluctuations. J Neurosci 18:8580-8589.

Egelman DM, Montague PR (1999) Calcium dynamics in the extracellular space of mammalian neural tissue. Biophys J 76:1856-1867.

Feldmeyer D, Egger V, Lubke J, Sakmann B (1999) Reliable synaptic connections between pairs of excitatory layer 4 neurones within a single "barrel" of developing rat somatosensory cortex. J Physiol (Lond) 521:169-190.

Francesconi A, Duvoisin RM (2004) Divalent cations modulate the activity of metabotropic glutamate receptors. J Neurosci Res 75:472-479.

Gama L, Wilt SG, Breitwieser GE (2001) Heterodimerization of calcium sensing receptors with metabotropic glutamate receptors in neurons. J Biol Chem 276:39053-39059.

Goda Y, Stevens CF (1994) Two components of transmitter release at a central synapse. Proc Natl Acad Sci USA 91:12942-12946.

Gudermann T, Kalkbrenner F, Schultz G (1996) Diversity and selectivity of receptor-G protein interaction. Annu Rev Pharmacol Toxicol 36:429-459.

Hardingham NR, Larkman AU (1998) Rapid report: the reliability of excitatory synaptic transmission in slices of rat visual cortex in vitro is temperature dependent. J Physiol (Lond) 507:249-256.

Hermans E, Challiss RA (2001) Structural, signalling and regulatory properties of the group I metabotropic glutamate receptors: prototypic family C G-protein-coupled receptors. Biochem J 359:465-484.

Hille B, Woodhull AM, Shapiro BI (1975) Negative surface charge near sodium channels of nerve: divalent ions, monovalent ions, and $\mathrm{pH}$. Philos Trans R Soc Lond B Biol Sci 270:301-318.

Iserhot C, Gebhardt C, Schmitz D, Heinemann U (2004) Glutamate transporters and metabotropic receptors regulate excitatory neurotransmission in the medial entorhinal cortex of the rat. Brain Res 1027:151-160.

Jin XT, Beaver CJ, Ji Q, Daw NW (2001) Effect of the group I metabotropic glutamate agonist DHPG on the visual cortex. J Neurophysiol 86:1622-1631.

Jonas P, Racca C, Sakmann B, Seeburg PH, Monyer H (1994) Differences in $\mathrm{Ca}^{2+}$ permeability of AMPA-type glutamate receptor channels in neocortical neurons caused by differential GluR-B subunit expression. Neuron 12:1281-1289.

Koester HJ, Johnston D (2005) Target cell-dependent normalization of transmitter release at neocortical synapses. Science 308:863-866.

Kubo Y, Miyashita T, Murata Y (1998) Structural basis for a $\mathrm{Ca}^{2+}$-sensing function of the metabotropic glutamate receptors. Science 279:1722-1725.

Kushmerick C, Price GD, Taschenberger H, Puente N, Renden R, Wadiche JI, Duvoisin RM, Grandes P, von Gersdorff H (2004) Retroinhibition of presynaptic $\mathrm{Ca}^{2+}$ currents by endocannabinoids released via postsynaptic mGluR activation at a calyx synapse. J Neurosci 24:5955-5965.

Larkman AU, Jack JJ, Stratford KJ (1997) Quantal analysis of excitatory synapses in rat hippocampal CA1 in vitro during low-frequency depression. J Physiol (Lond) 505:457-471.

Lou X, Scheuss V, Schneggenburger R (2005) Allosteric modulation of the presynaptic $\mathrm{Ca}^{2+}$ sensor for vesicle fusion. Nature 435:497-501.

Lujan R, Roberts JD, Shigemoto R, Ohishi H, Somogyi P (1997) Differential plasma membrane distribution of metabotropic glutamate receptors mGluR1 alpha, mGluR2 and mGluR5, relative to neurotransmitter release sites. J Chem Neuroanat 13:219-241.

Maejima T, Hashimoto K, Yoshida T, Aiba A, Kano M (2001) Presynaptic inhibition caused by retrograde signal from metabotropic glutamate to cannabinoid receptors. Neuron 31:463-475.

Mammen AL, Kameyama K, Roche KW, Huganir RL (1997) Phosphorylation of the alpha-amino-3-hydroxy-5-methylisoxazole4-propionic acid receptor GluR1 subunit by calcium/calmodulin-dependent kinase II. J Biol Chem 272:32528-32533.

Markram H, Lubke J, Frotscher M, Roth A, Sakmann B (1997) Physiology and anatomy of synaptic connections between thick tufted pyramidal neurones in the developing rat neocortex. J Physiol (Lond) 500:409-440.

Mason A, Nicoll A, Stratford K (1991) Synaptic transmission between individual pyramidal neurons of the rat visual cortex in vitro. J Neurosci 11:72-84. 
Massimini M, Amzica F (2001) Extracellular calcium fluctuations and intracellular potentials in the cortex during the slow sleep oscillation. J Neurophysiol 85:1346-1350.

McCormick DA, Connors BW, Lighthall JW, Prince DA (1985) Comparative electrophysiology of pyramidal and sparsely spiny stellate neurons of the neocortex. J Neurophysiol 54:782-806.

Meldrum BS (2000) Glutamate as a neurotransmitter in the brain: review of physiology and pathology. J Nutr 130:1007S-1015S.

Mintz IM, Sabatini BL, Regehr WG (1995) Calcium control of transmitter release at a cerebellar synapse. Neuron 15:675-688.

Morishita W, Kirov SA, Alger BE (1998) Evidence for metabotropic glutamate receptor activation in the induction of depolarization-induced suppression of inhibition in hippocampal CA1. J Neurosci 18:4870-4882.

Nicholson C, Bruggencate GT, Steinberg R, Stockle H (1977) Calcium modulation in brain extracellular microenvironment demonstrated with ionselective micropipette. Proc Natl Acad Sci USA 74:1287-1290.

Press WH, Teukolsky SA, Vetterling WT, Flannery BP (1993) Numerical recipes in C, Ed 2. Cambridge, UK: Cambridge UP.

Pumain R, Heinemann U (1985) Stimulus- and amino acid-induced calcium and potassium changes in rat neocortex. J Neurophysiol 53:1-16.

Qian J, Noebels JL (2001) Presynaptic $\mathrm{Ca}^{2+}$ channels and neurotransmitter release at the terminal of a mouse cortical neuron. J Neurosci 21:3721-3728.

Ruat M, Molliver ME, Snowman AM, Snyder SH (1995) Calcium sensing receptor: molecular cloning in rat and localization to nerve terminals. Proc Natl Acad Sci USA 92:3161-3165.

Rusakov DA (2001) The role of perisynaptic glial sheaths in glutamate spillover and extracellular $\mathrm{Ca}^{2+}$ depletion. Biophys J 81:1947-1959.

Rusakov DA, Fine A (2003) Extracellular $\mathrm{Ca}^{2+}$ depletion contributes to fast activity-dependent modulation of synaptic transmission in the brain. Neuron 37:287-297.

Rusakov DA, Kullmann DM, Stewart MG (1999) Hippocampal synapses: do they talk to their neighbours? Trends Neurosci 22:382-388.

Silver RA, Cull-Candy SG, Takahashi T (1996) Non-NMDA glutamate receptor occupancy and open probability at a rat cerebellar synapse with single and multiple release sites. J Physiol (Lond) 494:231-250.

Silver RA, Lubke J, Sakmann B, Feldmeyer D (2003) High-probability uniquantal transmission at excitatory synapses in barrel cortex. Science 302:1981-1984.

Smith SM, Bergsman JB, Harata NC, Scheller RH, Tsien RW (2004) Recordings from single neocortical nerve terminals reveal a nonselective cation channel activated by decreases in extracellular calcium. Neuron 41:243-256.

Stricker C, Redman SJ (2003) Quantal analysis based on density estimation. J Neurosci Methods 130:159-171.

Stricker C, Field AC, Redman SJ (1996) Statistical analysis of amplitude fluctuations in EPSCs evoked in rat CA1 pyramidal neurones in vitro. J Physiol (Lond) 490:419-441.

Tabata T, Aiba A, Kano M (2002) Extracellular calcium controls the dynamic range of neuronal metabotropic glutamate receptor responses. Mol Cell Neurosci 20:56-68.

Tabata T, Araishi K, Hashimoto K, Hashimotodani Y, van der Putten H, Bettler B, Kano M (2004) $\mathrm{Ca}^{2+}$ activity at $\mathrm{GABA}_{\mathrm{B}}$ receptors constitutively promotes metabotropic glutamate signaling in the absence of GABA. Proc Natl Acad Sci USA 101:16952-16957.

Tan SE, Wenthold RJ, Soderling TR (1994) Phosphorylation of AMPA-type glutamate receptors by calcium/calmodulin-dependent protein kinase II and protein kinase $\mathrm{C}$ in cultured hippocampal neurons. J Neurosci 14:1123-1129.

Thomas GD, O’Rourke B, Sikkink R, Rusnak F, Marban E, Victor RG (1997) Differential modulation of cortical synaptic activity by calcineurin (phosphatase 2B) versus phosphatases 1 and 2A. Brain Res 749:101-108.

van Dam EJ, Kamal A, Artola A, de Graan PN, Gispen WH, Ramakers GM (2004) Group I metabotropic glutamate receptors regulate the frequency-response function of hippocampal CA1 synapses for the induction of LTP and LTD. Eur J Neurosci 19:112-118.

Vassilev PM, Mitchel J, Vassilev M, Kanazirska M, Brown EM (1997) Assessment of frequency-dependent alterations in the level of extracellular $\mathrm{Ca}^{2+}$ in the synaptic cleft. Biophys J 72:2103-2116.

Wall MJ, Usowicz MM (1998) Development of the quantal properties of evoked and spontaneous synaptic currents at a brain synapse. Nat Neurosci 1:675-682.

Walmsley B, Edwards FR, Tracey DJ (1988) Nonuniform release probabilities underlie quantal synaptic transmission at a mammalian excitatory central synapse. J Neurophysiol 60:889-908.

Wang XF, Daw NW (1996) Metabotropic glutamate receptors potentiate responses to NMDA and AMPA from layer $\mathrm{V}$ cells in rat visual cortex. J Neurophysiol 76:808-815.

Wiest MC, Eagleman DM, King RD, Montague PR (2000) Dendritic spikes and their influence on extracellular calcium signaling. J Neurophysiol 83:1329-1337. 